\title{
PEMANFAATAN TEXT MINING PADA SISTEM PENGOLAHAN SKRIPSI MENGGUNAKAN ALGORITMA NAÏVE BAYES CLASSIFIER DAN SIMPLE ADDITIVE WEIGHTING
}

\author{
Firna Sholihuda(1), Bambang Yuwono(2), Heru Cahya Rustamadji(3) \\ Jurusan Teknik Informatika Fakultas Teknik Industri UPN “Veteran” Yogyakarta \\ Jl. Babarsari 2 Tambakbayan Yogyakarta \\ e-mail : firnansholihuda12@gmail.com ${ }^{(1)}$, bambangy@upnyk.ac.id(2), herucr@upnyk.ac.id (3)
}

\begin{abstract}
Minithesis is terminology for scientific paper made by college student as a terminal requirement for graduation. Proposal of minithesis will be managed by lecture to determine the advisor who has responsibility to guide the student until the minithesis is finished. Nowadays, the management of proposal still organized by manually ordered manner to match the advisor and the major of proposal. Application of information system to organize all of this process is very important to make it more efficient. To determine the major and the concentration of proposal, text mining method is required. Text mining works with preprocessing stage as tokenizing, filtering and stemming to gain each of root word in a complete sentence. After all of the root words is already collected, Naive Bayes Classifier algorithm is used to group the proposal with same major and concentration based on the preprocessing. Major and concentration of the proposal are criterias used to weight advisor's rank. Each advisor will be ranked with Simple Additive Weighting algorithm to match the major and concentration of proposal. Based on research, determination of major and concentration of proposal is able to determine the documents classification with $78 \%$ accuracy level. Result of advisor weighting rank based on their criteria and concentration may vary
\end{abstract}

Keywords : Text Mining, Tokenizing, Filltering, Stemming, Naïve Bayes Classifier, Simple Additive Weighting

\section{Abstrak}

Tahapan awal skripsi adalah pengajuan proposal skripsi. Proposal skripsi akan diproses untuk menentukan dosen pembimbing, kemudian skripsi dapat dilanjutkan ke tahap penyusunan. Saat ini pengolahan skripsi menggunakan cara manual, dari penentuan dosen pembimbing hingga pengumpulan laporan akhir. Koordinator Skripsi juga harus mencocokkan data proposal dengan data dosen pembimbing secara manual. Maka, penggunaan Sistem Informasi dapat membantu menentukan dosen pembimbing dan sebagai layanan skripsi. Langkah awal dalam menentukan dosen pembimbing adalah mengetahui tema dan konsentrasi proposal skripsi. Untuk mengetahui tema dan konsentrasi proposal dilakukan analisis isi proposal menggunakan metode Text Mining. Text Mining bekerja dengan cara preprocessing menggunakan tokenizing, filtering, dan stemming untuk mendapatkan kata dasar dari setiap kata dalam setiap kalimat. Kemudian melakukan klasifikasi dokumen proposal sesuai dengan tema dan konsentrasi menggunakan algoritma Naïve Bayes Classifier berdasarkan hasil preprocessing. Tema dan konsentrasi merupakan salah satu kriteria penentukan dosen pembimbing menggunakan algoritma Simple Additive Weighting untuk dilakukan perangkingan pembobotan setiap dosen. Berdasarkan hasil penelitian yang telah dilakukan, proses penentuan tema dan konsentrasi dari proposal skripsi mahasiswa dapat membantu dalam melakukan klasifikasi dokumen dengan tingkat akurasi mencapai $78 \%$. Pembobotan dosen pembimbing proposal skripsi sesuai dengan kriteria menunjukkan hasil dengan nilai perangkingan yang beragam sesuai dengan bobot kriteria setiap dosen pembimbing.

Kata Kunci : Text Mining, Tokenizing, Filltering, Stemming, Naïve Bayes Classifier, Simple Additive Weighting 


\section{PENDAHULUAN}

Mahasiswa mempunyai kewajiban untuk membuat suatu penelitian sebagai syarat lulus dan mendapatkan gelar sarjana dari Perguruan Tinggi. Proses pengajuan penelitian atau skripsi yang dilakukan oleh mahasiswa berbeda-beda, ada yang mengajukan dengan cara datang langsung ke jurusan atau fakultas dan ada juga yang memanfaatkan sistem informasi khusus untuk layanan skripsi. Sistem informasi layanan skripsi dapat mempermudah mahasiswa maupun dosen dalam pengajuan proposal skripsi, penetapan dosen pembimbing, penentuan jadwal sidang skripsi, bahkan pengumpulan skripsi jika sudah dinyatakan lulus. Jurusan IImu Komunikasi Universitas Pembangunan Nasional "Veteran" Yogyakarta tidak melibatkan sistem informasi dalam mengelola skripsi mahasiswa.

Pengelolaan tanpa melibatkan sistem informasi pada jurusan IImu Komunikasi dilakukan mulai dari proses pengajuan proposal, penentuan dosen pembimbing, sampai dengan pengumpulan file skripsi jika sudah dinyatakan lulus. Dimana proses pengelolaan skripsi hanya dilakukan oleh Sekretaris Jurusan, mahasiswa akan mengumpulkan proposal dalam bentuk hardcopy kepada Sekretaris Jurusan dan mencatat pada buku sebagai catatan riwayat pengajuan proposal.

Proses pengajuan proposal skripsi sampai dengan penentuan dosen pembimbing memerlukan waktu yang cukup lama, Sekretaris Jurusan harus melakukan pencocokan pada daftar dosen sesuai konsentrasi dan tema, kuota setiap dosen per satu semester, dan bobot dosen pembimbing pada setiap proposal skripsi yang masuk. Dosen pembimbing juga tidak mengetahui berapa jumlah mahasiswa yang sedang dibimbing, sudah dinyatakan lulus atau belum, dan pengumpulan laporan skripsi masih menggunakan CD per skripsi juga menjadi masalah utama pada Jurusan IImu Komunikasi.

Permasalahan utama dalam pengelolaan skripsi menjadi permasalahan yang harus di selesaikan pada jurusan IImu Komunikasi UPN "Veteran" Yogyakarta. Maka dari itu solusi dari penelitian ini adalah mengembangkan sistem pengolahan skripsi dengan memanfaatkan Text Mining, Naïve Bayes Classifier (NBC) dan Simple Additive Weighting (SAW) yaitu sistem informasi layanan skripsi untuk pengolahan skripsi mulai dari pengajuan proposal sampai dengan pengumpulan file laporan skripsi.

Untuk menentukan konsentrasi dan tema proposal skripsi, sekretaris jurusan harus membaca satu per satu dari proposal mahasiswa sehingga penentuan konsentrasi dan tema memerlukan waktu yang cukup lama. Sehingga pada penelitian ini digunakan text mining untuk proses mengeksplorasi dan menganalisis sejumlah besar data teks tidak terstruktur atau jumlahnya semakin bertambah banyak. Penggunaan text mining dilakukan untuk membantu dalam menganalisis teks sehingga proses klasifikasi teks berdasarkan tema dan konsentrasi menggunakan algoritma Naïve Bayes Classifier akan semakin baik.

Algoritma Naïve Bayes Classifier adalah algoritma untuk klasifikasi data ataupun teks yang bekerja dengan baik dibandingkan algoritma klasifikasi lainnya. Pada penelitian sebelumnya, Naïve Bayes Classifier memberikan hasil yang lebih signifikan dibandingkan dengan Support Vector Machine untuk klasifikasi judul skripsi (Hidayatullah \& Ma'arif, 2016). Algoritma Naïve Bayes Classifier juga memberikan akurasi yang cukup tinggi pada pengklasifikasian teks yaitu sebesar 92,67\% (Handayani \& Pribadi, 2015), kemudian penggunaan Naïve Bayes Classifier untuk kategorisasi tugas akhir berdasarkan abstrak mempunyai akurasi sebesar $87 \%$ (Hermanto, 2016).

Algoritma Simple Additive Weighting adalah algoritma untuk menentukan atau memberikan pertimbangan keputusan berdasarkan kriteria tertentu. Konsentrasi dosen, kompetensi setiap dosen, jabatan fungsional dosen, dan jumlah bimbingan skripsi yang masih aktif menjadi kriteria untuk dilakukan perhitungan pembobotan dengan algoritma ini. Pada penelitian sebelumnya, penggunaan Simple Additive Weighting untuk penentuan dosen pembimbing mampu memberikan rekomendasi dosen pembimbing berdasarkan kriteria-kriteria yang digunakan untuk penentuan dosen pembimbing skripsi (Laengge, Wowor, \& Putro, 2016). Metode Simple 
Additive Weighting juga akan memberikan pembobotan alternatif dengan bobot terbesar merupakan alternatif pilihan yang akan ditetapkan menjadi dosen pembimbing (Anggraeni,2017).

Proposal skripsi mahasiswa menjadi bahan untuk penentuan dosen pembimbing skripsi. Penelitian ini akan menganalisis proposal skripsi yang dikumpulkan oleh mahasiswa. Proposal mahasiswa akan dianalisis dan diekstraksi menggunakan text mining untuk dapat dilakukan klasifikasi berdasarkan tema dan konsentrasi menggunakan Algoritma Naïve Bayes Classifier.

Kemudian dilakukan pembobotan alternatif dosen pembimbing proposal skripsi menggunakan Simple Additive Weighting dengan beberapa kriteria tertentu. Hal ini diharapkan dapat membantu penyelesaian permasalahan layanan skripsi dengan menggunakan layanan sistem informasi jurusan IImu Komunikasi UPN "Veteran” Yogyakarta.

Tujuan penelitian ini adalah menentukan dosen pembimbing setiap proposal skripsi yang diajukan oleh mahasiswa sesuai dengan konsentrasi dan tema proposal skripsi. Manfaat penelitian ini adalah memudahkan Jurusan IImu Komunikasi dalam melaksanakan proses pengolahan skripsi mulai dari pengajuan proposal hingga pengumpulan laporan akhir skripsi jika sudah dinyatakan lulus dan efisiensi maupun efektivitas waktu dalam pengolahan skripsi mahasiswa.

\section{METODOLOGI PENELITIAN}

\subsection{Arsitektur Sistem}

Perancangan arsitektur sistem mengambarkan sebuah proses berjalannnya sebuah sistem. Arsitektur sistem ini terdiri dari admin dan user (mahasiswa dan dosen). Dimana fungsi admin dan user memiliki perbedaan dalam mengakses sistem. Arsitektur sistem menggambarkan sistem terdiri dari text mining, naïve bayes classifier, dan simple additive weighting yang akan dilakukan pemrosesan proposal penelitian. Sistem terhubung dengan database untuk mengelola atau menampilkan sebuah data. (Gambar 1)

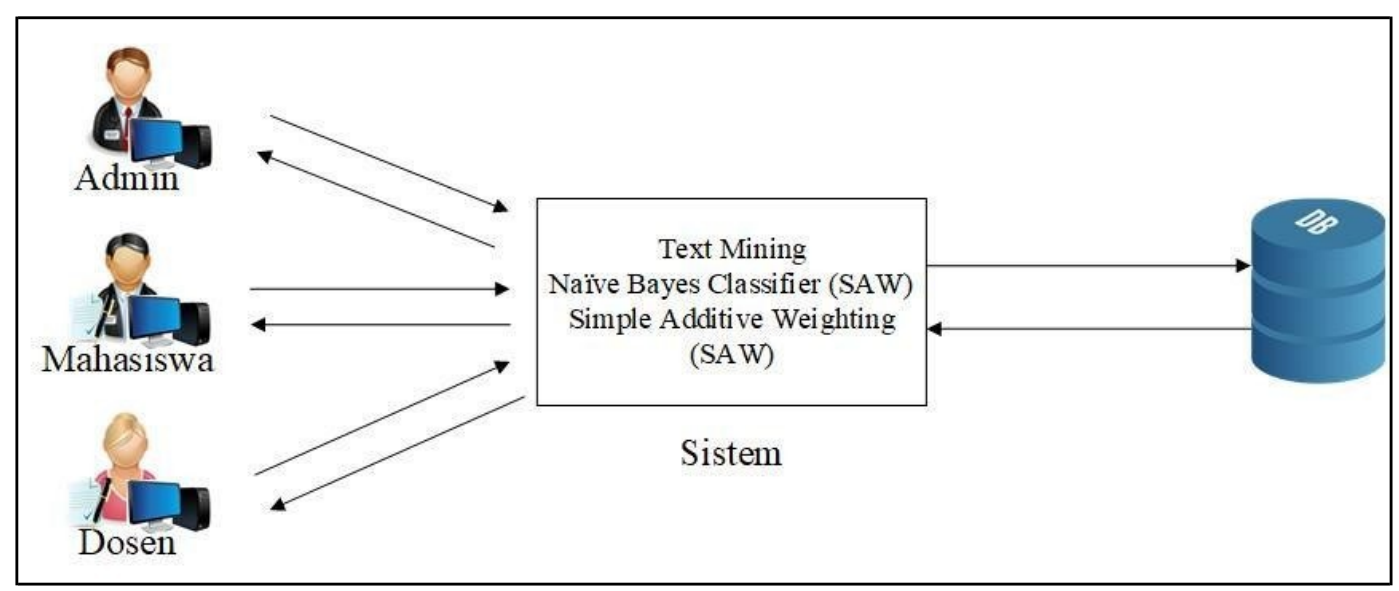

Gambar 1. Perancangan Arsitektur Sistem

\subsection{Perancangan Proses}

Perancangan proses terdapat flowchart Naïve Bayes Classifier dan Simple Additive Weighting. Flowchart Naïve Bayes Classifier merupakan flowchart untuk klasifikasi teks. Proses klasifikasi teks akan dilakukan setelah teks dilakukan proses preprocessing, teks proposal berbentuk array akan di klasifikasikan sesuai tema dan konsentrasi proposal. Tema dan konsentrasi proposal dibagi menjadi empat yaitu Advertising, Broadcasting, Jurnalistik, dan Public Relation. (Gambar 2) 


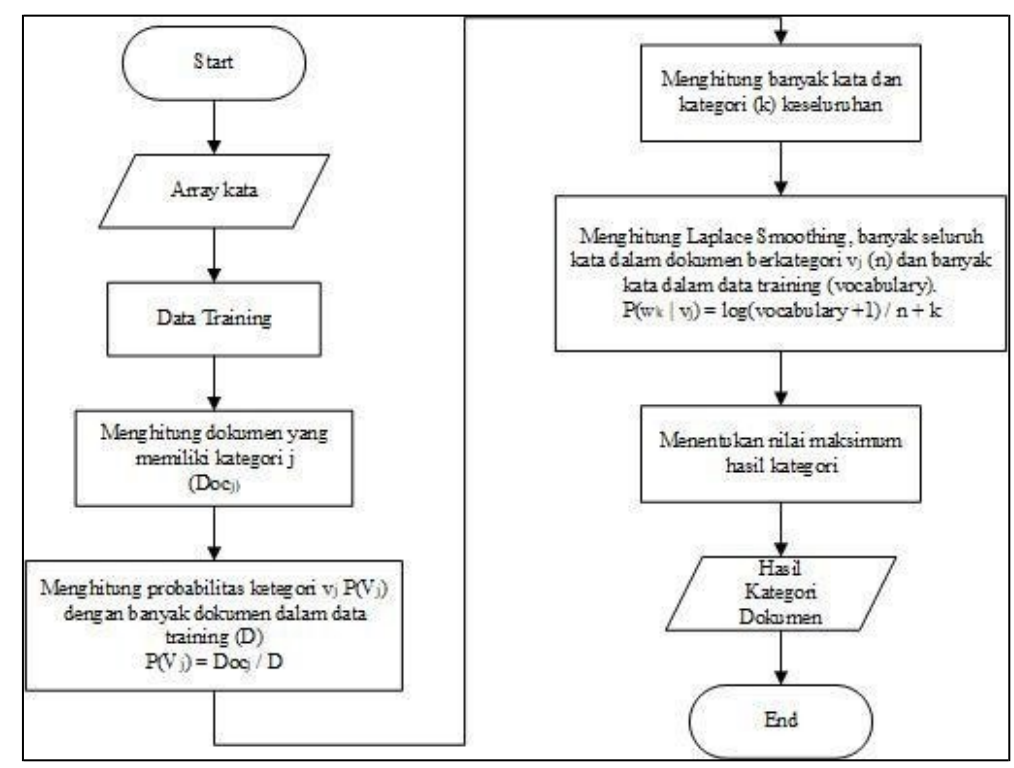

Gambar 2. Flowchart NaïveBayes Classifier

Langkah proses klasifikasi teks menggunakan Naïve Bayes Classifier adalah sebagai berikut:

1. Setelah proses stemming pada preprocessing, hasil dari proses stemming berupa array kata akan dimasukkan untuk diolah menggunakan algoritma Naïve Bayes Classifier.

2. Mengambil data training pada database dan tabel frekuensi kata. Data training digunakan untuk membentuk kerangka pikir sistem agar dapat mengidentifikasi data uji yang dimasukkan.

3. Selanjutnya menghitung dokumen yang memiliki kategori tertentu (Doc j) pada data training dataset.

4. Kemudian menghitung probabilitas kategori $\mathrm{Vj}, \mathrm{P}(\mathrm{Vj})$ dengan banyak dokumen dalam dokumen dalam data training $(\mathrm{D})$, dengan rumus:

$\mathrm{P}(\mathrm{Vj})=$ Docj $/ \mathrm{D}$

5. Jika telah diketahui berapa banyak dokumen dalam data training, kemudian menghitung banyak kata dan kategori keseluruhan (k).

6. Tahapan selanjutnya adalah menghitung Laplace Smoothing, yaitu menangani nilai probabilitas 0 dengan menambah 1 pada setiap data training. Menghitung banyak seluruh kata dalam dokumen berkategori vj (n) dan banyak kata dalam data training (vocabulary). dengan rumus:

$P(w k \mid v j)=\log ($ vocabulary +1$) / n+k$

7. Kemudian menentukan nilai maksimum hasil kategori, dan membandingkan nilai masingmasing kategori, dan menghasilkan kategorisasi dokumen proposal mahasiswa.

8. Proses selesai.

Flowchart Simple Additive Weighting merupakan flowchart proses penentuan dosen pembimbing proposal. Proses ini adalah menghitung pembobotan kriteria setiap dosen pembimbing. Langkah-langkah penentuan dosen pembimbing menggunakan Simple Additive Weighting adalah sebagai berikut: (Gambar 3)

1. Setelah menentukan tema dan konsentrasi dari proposal skripsi mahasiswa maka dilakukan penentuan dosen pembimbing dengan cara memasukkan kriteria Konsentrasi dan Kompetensi. 
2. Kemudian output dari input kriteria konsentrasi dan kompetensi akan diolah menggunakan Simple Additive Weighting dengan menentukan bobot setiap dosen dengan kriteria uji yang sama

3. Tahapan selanjutnya adalah membuat matriks keputusan berdasarkan bobot kriteria uji.

4. Setelah terbentuk matriks keputusan berdasarkan bobot kriteria uji maka dilakukan proses penentuan nilai maksimal (Max xij) dan nilai minimal (Min xij) setiap kriteria pada dosen pembimbing.

5. Normalisasi matriks keputusan (rij) dengan kriteria yang dicari atau baris dan kolom matriks (xij) dan nilai max atau min. Menggunakan nilai Max xij, jika menggunakan atribut benefit, yaitu nilai terbesar adalah nilai terbaik, dan menggunakan nilai Min xij, apabila menggunakan atribut cost yaitu nilai terkecil adalah nilai terbaik.

$\mathrm{rij}=\mathrm{xij} / \max \mathrm{xij}$

$\mathrm{rij}=\min \mathrm{xij} / \mathrm{xij}$

6. Tahapan selanjutnya adalah menghitung nilai akhir alternatif (Vi) setiap hasil normalisasi matriks sesuai dengan dosen pembimbing berdasarkan jumlah dari normalisasi matriks (rij) dengan bobot kriteria uji (wj ) yang sudah ditentukan bobot dari masing-masing kriteria.

$\mathrm{Vi}=\operatorname{SUM}(\mathrm{wj} \cdot \mathrm{rij})$

7. Setelah menghitung nilai akhir alternatif (Vi), kemudian melakukan proses perangkingan berdasarkan nilai tertinggi dari ( $\mathrm{Vi})$ masing-masing dosen. Hasil penentuan dosen pembimbing telah selesai.

8. Proses selesai.

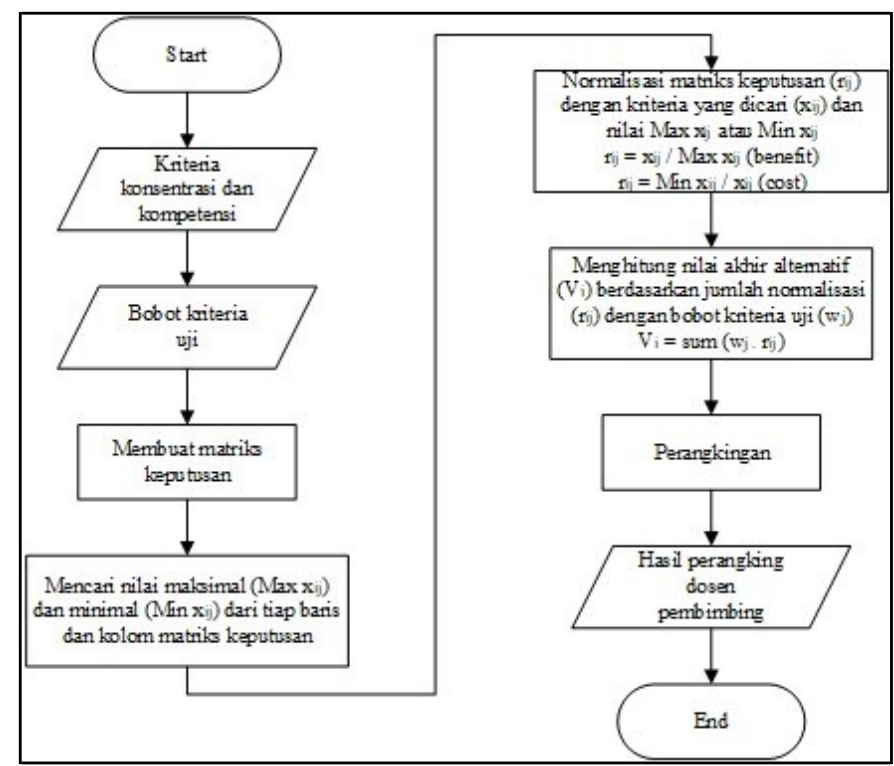

Gambar 3. Flowchart Simple Additive Weighting

\section{HASIL DAN PEMBAHASAN}

Hasil dan pembahasan merupakan tahap di dalam sistem dimana sistem siap dioperasikan dengan keadaan yang sesungguhnya. Hasil dari penelitian ini adalah menentukan tema dan konsentrasi proposal skripsi dan menentukan dosen pembimbing skripsi.

\subsection{Antarmuka Sistem}


Halaman utama sistem memuat halaman login untuk masuk sebagai admin, dosen, atau mahasiswa ke dalam sistem. (Gambar 4)

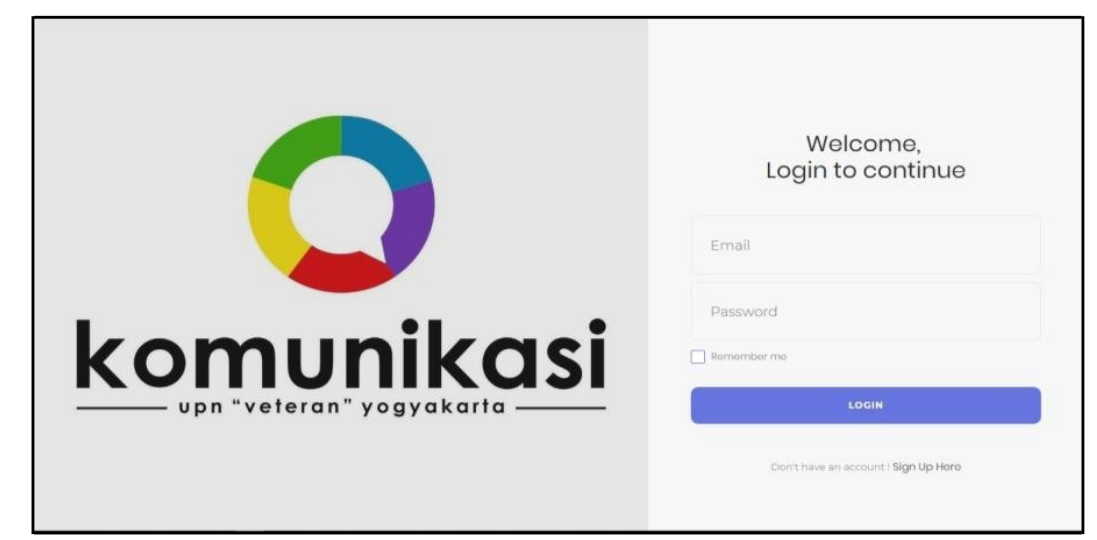

Gambar 4. Halaman Utama Sistem

Halaman ini adalah halaman hasil pengolahan text mining dan naïve bayes classifier untuk menentukan tema dan konsentrasi proposal. Bentuk dari isi teks proposal adalah hasil preprocessing menggunakan tokenizing, filtering, dan stemming. (Gambar 5)

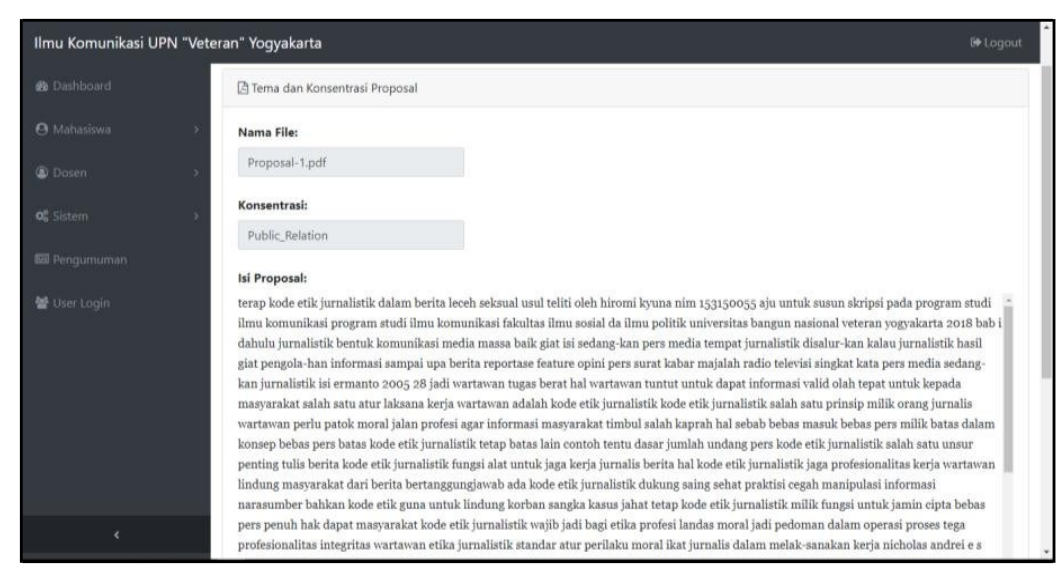

Gambar 5. Halaman Penentuan Tema dan Konsentrasi Proposal

Halaman penentuan dosen pembimbing merupakan halaman hasil pengolahan algoritma simple additive weighting untuk menentukan dosen pembimbing dengan melakukan perangkingan. (Gambar 6) 


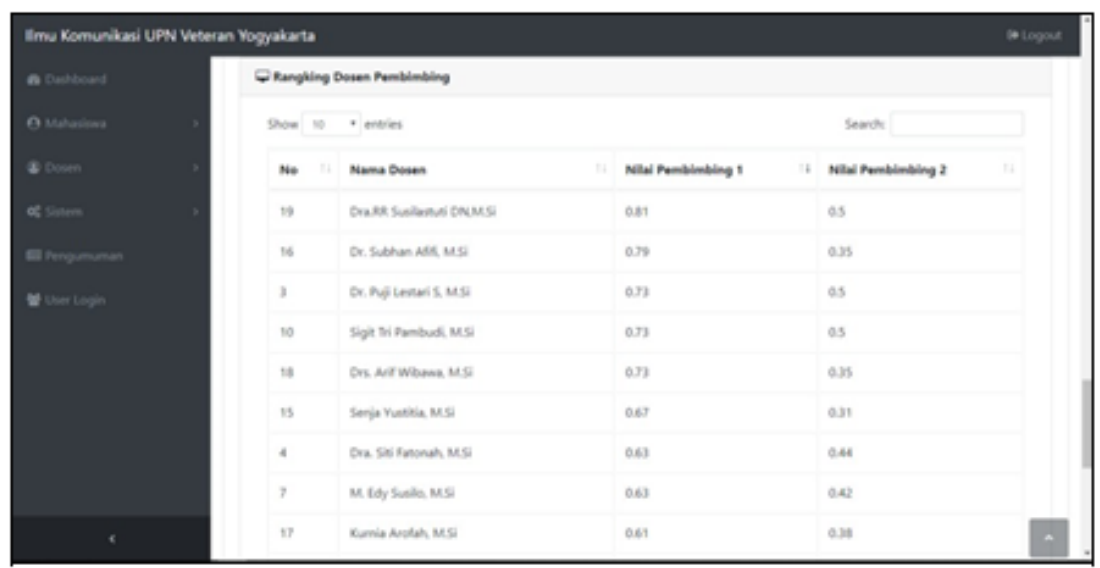

Gambar 6. Halaman Penentuan Dosen Pembimbing

\subsection{Pengujian Data}

Data yang digunakan dalam penelitian ini merupakan data proposal mahasiswa dan data pembobotan dosen pembimbing jurusan IImu Komunikasi UPN "Veteran" Yogyakarta. Proposal mahasiswa yang dimasukkan berbentuk pdf, dan data pembobotan dosen pembimbing berbentuk angka sesuai bobot kriteria masing-masing dosen pembimbing.

Tema dan konsentrasi terdapat empat kategori yaitu Advertising, Broadcasting, Jurnalistik, dan Public Relation. Perbandingan klasifikasi proposal skripsi menggunakan sistem dan manual dengan 18 data uji (Gambar 7). Kemudian pengujian sistem menggunakan Naïve Bayes Classifier dapat dilihat pada hasil confusion matrix mencari nilai presisi, recall, dan akurasi. (Tabel 1 dan Tabel 2)

\section{PERBANDINGAN KLASIFIKASI DATA TESTING}

nManual @istem

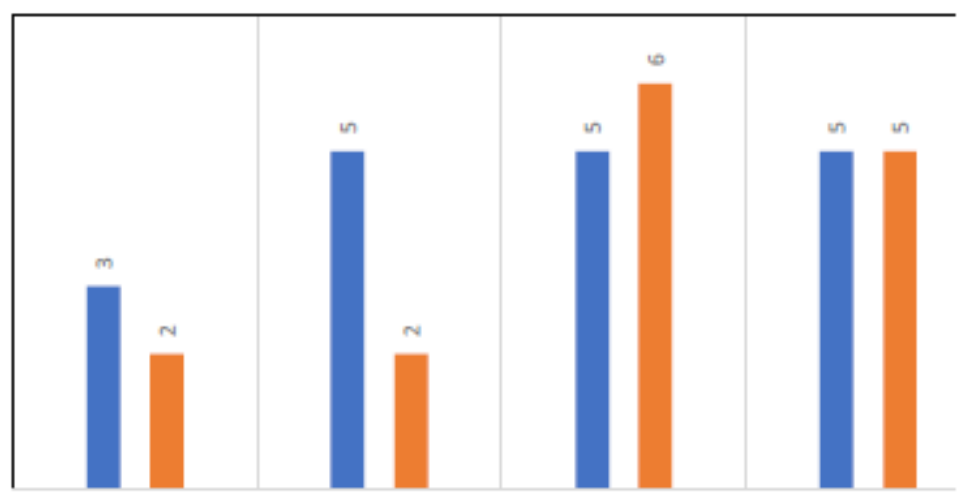

Gambar 7. Grafik Perbandingan Klasifikasi Data Testing

Tabel 1. Tabel Confusion Matrix

\begin{tabular}{|c|l|c|c|}
\hline \multicolumn{2}{|c|}{} & \multicolumn{3}{|c|}{ Sistem } \\
\cline { 2 - 4 } \multicolumn{2}{|c|}{ Manual } & Terklasifikasi Benar & Terklasifikasi Salah \\
\cline { 2 - 4 } & Senar & $13($ TP) & 3 (FN) \\
\hline
\end{tabular}

Tabel 2. Hasil Pengujian Mengunakan Naïve Bayes Classifier 


\begin{tabular}{|c|c|c|c|}
\hline Data & Presisi & Recall & Akurasi \\
\hline 18 dokumen & $72 \%$ & 82 & 78 \\
\hline
\end{tabular}

Hasil pengujian sistem menggunakan algoritma Naïve Bayes Classifier menghasilkan $78 \%$ akurasi. Kemudian pengujian Simple Additive Weighting menggunakan data sample beberapa dosen pembimbing. (Tabel 3)

Tabel 3. Daftar Dosen Pembimbing

\begin{tabular}{|c|l|l|l|l|l|}
\hline Alternatif & $\begin{array}{c}\text { Jabatan } \\
\text { Fungsional }\end{array}$ & Konsentrasi & Kompetensi & $\begin{array}{c}\text { Kuota } \\
\text { P1 }\end{array}$ & $\begin{array}{c}\text { Kuota } \\
\text { P2 }\end{array}$ \\
\hline A1 & $\begin{array}{l}\text { Lektor } \\
\text { Kepala }\end{array}$ & $\begin{array}{l}\text { Public } \\
\text { Relation }\end{array}$ & $\begin{array}{l}\text { Pemasaran, } \\
\text { Organisasi, } \\
\text { Budaya }\end{array}$ & 9 & 11 \\
\hline A2 & Lektor & Advertising & $\begin{array}{l}\text { Pemasaran, } \\
\text { Politik, Media, } \\
\text { Budaya }\end{array}$ & 9 & 15 \\
\hline A3 & Lektor & Jurnalistik & $\begin{array}{l}\text { Semiotika, } \\
\text { Media }\end{array}$ & 11 & 10 \\
\hline A4 & Asisten Ahli & Jurnalistik & $\begin{array}{l}\text { Organisasi, } \\
\text { Politik }\end{array}$ & 11 & 8 \\
\hline A5 & Asisten Ahli & Broadcasting & $\begin{array}{l}\text { Semiotika, } \\
\text { Media, } \\
\text { Radio,TV, Film }\end{array}$ & 9 & 14 \\
\hline
\end{tabular}

Tabel 4. Pembobotan Kriteria Konsentrasi Dosen Pembimbing

\begin{tabular}{|l|l|l|l|l|}
\hline \multirow{2}{*}{$\#$} & \multicolumn{3}{|c|}{ Konsentrasi } \\
\cline { 2 - 5 } & Advertising & Broadcasting & Jurnalistik & Public Relation \\
\hline A1 & 0.33 & 0.16 & 0.67 & 1 \\
\hline A2 & 1 & 0.83 & 0.67 & 0.16 \\
\hline A3 & 0.5 & 0.33 & 1 & 0.33 \\
\hline A4 & 0.16 & 0.16 & 1 & 0.83 \\
\hline A5 & 0.67 & 1 & 0.5 & 0.16 \\
\hline
\end{tabular}

Tabel 5. Pembobotan Kriteria Kompetensi Dosen Pembimbing

\begin{tabular}{|l|c|c|c|c|c|}
\hline \multirow{2}{*}{$\#$} & \multicolumn{5}{|c|}{ Kompetensi } \\
\cline { 2 - 6 } & CSR & Strategi PR & K.Pemasaran & K.Organisasi & Semiotika \\
\hline A1 & 0.5 & 0.83 & 1 & 1 & 0.16 \\
\hline A2 & 0.16 & 0.16 & 1 & 0.16 & 0.16 \\
\hline A3 & 0.16 & 0.16 & 0.16 & 0.83 & 1 \\
\hline A4 & 0.16 & 0.16 & 0.16 & 1 & 0.67 \\
\hline A5 & 0.16 & 0.16 & 0.83 & 0.16 & 1 \\
\hline
\end{tabular}

Tabel 6. Lanjutan Pembobotan Kriteria Kompetensi Dosen Pembimbing

\begin{tabular}{|l|c|c|c|c|c|}
\hline \multirow{2}{*}{$\#$} & \multicolumn{5}{|c|}{ Kompetensi } \\
\cline { 2 - 6 } & Branding & K.Politik & Media & K.Budaya & Radio TV Film \\
\hline A1 & 0.16 & 0.16 & 0.16 & 1 & 0.16 \\
\hline A2 & 0.33 & 1 & 1 & 1 & 0.67 \\
\hline A3 & 0.16 & 0.5 & 1 & 0.67 & 0.33 \\
\hline A4 & 0.33 & 1 & 0.83 & 0.83 & 0.33 \\
\hline A5 & 0.33 & 0.16 & 1 & 0.33 & 1 \\
\hline
\end{tabular}

Tabel 7. Pembobotan Kriteria Jabatan Fungsional dan Kuota Dosen Pembimbing 


\begin{tabular}{|l|c|c|c|c|}
\hline \multirow{2}{*}{$\#$} & \multicolumn{4}{|c|}{ Jabatan Fungsional dan Kuota } \\
\cline { 2 - 5 } & $\begin{array}{c}\text { Jab. Fungsional } \\
\text { P1 }\end{array}$ & $\begin{array}{c}\text { Jab. Fungsional } \\
\text { P2 }\end{array}$ & Kuota P1 & Kuota P2 \\
\hline A1 & 0.75 & 0.5 & 1 & 0.75 \\
\hline A2 & 0.5 & 0.75 & 0.25 & 0.75 \\
\hline A3 & 0.5 & 0.75 & 0.5 & 1 \\
\hline A4 & 0.25 & 1 & 0.5 & 1 \\
\hline A5 & 0.25 & 1 & 0.25 & 0.75 \\
\hline
\end{tabular}

Data uji adalah proposal dengan judul Strategi Komunikasi Pemasaran Dengan Media Sosial Untuk Meningkatkan Pengunjung dengan konsentrasi Advertising, dan kompetensi Komunikasi Pemasaran. Berikut adalah perhitungan untuk mendapatkan perangkingan pembimbing $\mathrm{I}$.

\begin{tabular}{|cccc|}
\hline 0.33 & 1 & 0.75 & 1 \\
1 & 1 & 0.5 & 0.25 \\
0.5 & 0.16 & 0.5 & 0.5 \\
0.16 & 0.16 & 0.25 & 0.5 \\
0.67 & 0.83 & 0.25 & 0.25 \\
\hline
\end{tabular}

Gambar 8. Matriks Keputusan Pembimbing I

$$
\begin{aligned}
& r_{11}=\frac{0.33}{\max \{0.33 ; 1 ; 0.5 ; 0.16 ; 0.67\}}=\frac{0.33}{1}=0.33 \\
& r_{12}=\frac{1}{\max \{0.33 ; 1 ; 0.5 ; 0.16 ; 0.67\}}=\frac{1}{1}=1 \\
& r_{13}=\frac{0.5}{\max \{0.33 ; 1 ; 0.5 ; 0.16 ; 0.67\}}=\frac{0.5}{1}=0.5 \\
& r_{14}=\frac{0.16}{\max \{0.33 ; 1 ; 0.5 ; 0.16 ; 0.67\}}=\frac{0.16}{1}=0.16 \\
& r_{15}=\frac{0.67}{\max \{0.33 ; 1 ; 0.5 ; 0.16 ; 0.67\}}=\frac{0.67}{1}=0.67 \\
& r_{21}=\frac{1}{\max \{1 ; 1 ; 0.16 ; 0.16 ; 0.83\}}=\frac{1}{1}=1 \\
& r_{22}=\frac{1}{\max \{1 ; 1 ; 0.16 ; 0.16 ; 0.83\}}=\frac{1}{1}=1 \\
& r_{23}=\frac{0.16}{\max \{1 ; 1 ; 0.16 ; 0.16 ; 0.83\}}=\frac{0.16}{1}=0.16 \\
& r_{24}=\frac{0.16}{\max \{1 ; 1 ; 0.16 ; 0.16 ; 0.83\}}=\frac{0.16}{1}=0.16 \\
& r_{25}=\frac{0.83}{\max \{1 ; 1 ; 0.16 ; 0.16 ; 0.83\}}=\frac{0.83}{1}=0.83
\end{aligned}
$$

$$
\begin{aligned}
& r_{31}=\frac{0.75}{\max \{0.75 ; 0.5 ; 0.5 ; 0.25 ; 0.25\}}=\frac{0.75}{0.75}=1 \\
& r_{32}=\frac{0.5}{\max \{0.75 ; 0.5 ; 0.5 ; 0.25 ; 0.25\}}=\frac{0.5}{0.75}=0.66
\end{aligned}
$$

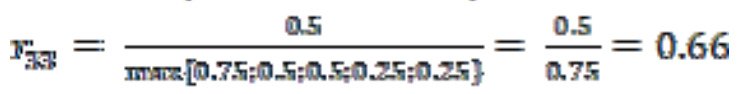

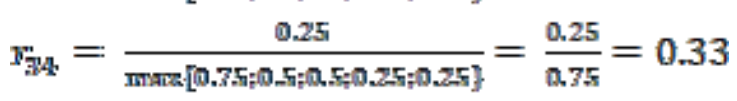

$$
\begin{aligned}
& r_{35}=\frac{0.25}{\max \{0.75 ; 0.5 ; 0.5 ; 0.25 ; 0.25\}}=\frac{0.25}{0.75}=0.33 \\
& r_{41}=\frac{1}{\max \{1 ; 0.25 ; 0.5 ; 0.5 ; 0.25\}}=\frac{1}{1}=1 \\
& r_{42}=\frac{0.25}{\max \{1 ; 0.25 ; 0.5 ; 0.5 ; 0.25\}}=\frac{0.25}{1}=0.25 \\
& r_{43}=\frac{0.5}{\max \{1 ; 0.25 ; 0.5 ; 0.5 ; 0.25\}}=\frac{0.5}{1}=0.5 \\
& r_{44}=\frac{0.5}{\max \{1 ; 0.25 ; 0.5 ; 0.5 ; 0.25\}}=\frac{0.5}{1}=0.5 \\
& r_{45}=\frac{0.25}{\max \{1 ; 0.25 ; 0.5 ; 0.5 ; 0.25\}}=\frac{0.25}{1}=0.25
\end{aligned}
$$

\begin{tabular}{|cccc|}
\hline 0.33 & 1 & 1 & 1 \\
1 & 1 & 0.6 & 0.25 \\
0.5 & 0.16 & $\hat{0}$ & 0.6 \\
0.16 & 0.16 & 0.33 & 0.5 \\
0.67 & 0.83 & 0.33 & 0.25 \\
\hline
\end{tabular}

Gambar 9. Normalisasi Matriks Keputusan Pembimbing I 
Kemudian melakukan perhitungan pada setiap alternatif untuk memperoleh perangkingan dengan bobot kriteria Konsentrasi 0.3 , kriteria Kompetensi 0.2, kriteria Jabatan Fungsional 0.25, dan kriteria Kuota 0.25 .

$$
\begin{aligned}
& V_{1}=(0.3)(0.33)+(0.2)(1)+(0.25)(1)+(0.25)(1)=0.799=0.8 \\
& V_{2}=(0.3)(1)+(0.2)(1)+(0.25)(0.66)+(0.25)(0.25)=0.727=0.73 \\
& V_{3}=(0.3)(0.5)+(0.2)(0.16)+(0.25)(0.66)+(0.25)(0.5)=0.472=0.47 \\
& V_{4}=(0.3)(0.16)+(0.2)(0.16)+(0.25)(0.33)+(0.25)(0.5)=0.287=0.29 \\
& V_{5}=(0.3)(0.67)+(0.2)(0.83)+(0.25)(0.33)+(0.25)(0.25)=0.512=0.51
\end{aligned}
$$

Tabel 8. Tabel Perangkingan Dosen Pembimbing I

\begin{tabular}{|c|c|c|c|}
\hline Dosen & Nilai & Rangking & Keterangan \\
\hline A & 0.8 & 1 & Direkomendasikan \\
\hline A & 0.73 & 2 & Direkomendasikan \\
\hline A & 0.47 & 5 & - \\
\hline A & 0.29 & 4 & - \\
\hline A & 0.51 & 3 & - \\
\hline
\end{tabular}

Pada perangkingan dosen pembimbing I dapat disimpulkan bahwa dosen A1 dan A2 direkomendasikan sebagai dosen pembimbing I dari proposal Strategi Komunikasi Pemasaran Dengan Media Sosial Untuk Meningkatkan Pengunjung dengan konsentrasi Advertising dengan nilai A1 adalah 0.8 dan nilai A2 adalah 0.73 .

\section{KESIMPULAN}

Mahasiswa dapat melakukan pengajuan proposal, melihat jadwal pendadaran, dan mengumpulkan laporan akhir skripsi, sedangkan dosen dapat melihat data pembimbing, data dosen, jadwal pendadaran, dan mengakses laporan akhir yang dikumpulkan mahasiswa. Sekretaris Jurusan dapat melakukan pengolahan skripsi untuk menentukan tema dan konsentrasi skripsi dan menentukan dosen pembimbing serta mengakses semua data pada sistem. Kesimpulan yang dapat diambil dari penelitian ini antara lain:

1. Hasil penggunaan sistem informasi skripsi ini mampu menjawab kebutuhan dari mahasiswa, dosen, serta sekretaris jurusan yang ada di IImu Komunikasi UPN "Veteran" Yogyakarta yaitu mampu membantu mahasiswa dalam pengajuan proposal dan laporan akhir, dan sekretaris jurusan dalam memproses proposal mahasiswa yang masuk untuk menentukan tema dan konsentrasi proposal maupun menentukan dosen pembimbing dari proposal.

2. Sistem ini melakukan analisis dan klasifikasi proposal mahasiswa dengan baik. Hasil pengujian pada sistem yang dibangun memperlihatkan bahwa algoritma Naïve Bayes Classifier memberikan presisi sebesar $72 \%$, recall sebesar $82 \%$, dan akurasi sebesar $78 \%$.

3. Algoritma Simple Additive Weighting bergantung pada pembobotan setiap kriteria, jika bobot masing-masing kriteria diubah maka perangkingan data akan berubah pula, dan semakin besar nilai bobot suatu kriteria maupun sub kriteria maka semakin besar kemungkinan alternatif tersebut dipilih karena nilai perangkinganya semakin tinggi.

\section{DAFTAR PUSTAKA}

Agusta, L. 2009. Perbandingan Algoritma Stemming Porter Dengan Algoritma Nazief dan Adriani Untuk Stemming Dokumen Teks Bahasa Indonesia. Konferensi Nasional Sistem dan Informatika 2009. 
Anggraeni, E. Y. 2017. Metode Simple Additive Weighting (SAW) Dalam Sistem Pendukung Keputusan Menentukan Dosen Pembimbing Skripsi Di Stmik Pringsewu. Jurnal TAM (Technology Acceptance Model), 5, pp. 8-11.

Ariadi, D., \& Fithriasari, K. (2015). Klasifikasi Berita Indonesia Menggunakan Metode Naive Bayesian Classification dan Support Vector Machine dengan Confix Stripping Stemmer. 4.

Efendi, Z., \& Mustakim, M. 2017. Text Mining Classification Sebagai Rekomendasi Dosen Pembimbing Tugas Akhir Program Studi Sistem Informasi. In Seminar Nasional Teknologi Informasi Komunikasi dan Industri pp. 235-242.

Handayani, F., \& Pribadi, F. S. (2015). Implementasi Algoritma Naive Bayes Classifier dalam Pengklasifikasian Teks Otomatis Pengaduan dan Pelaporan Masyarakat melalui Layanan Call Center 110. Jurnal Teknik Elektro, 7.

Henry, W. 2009. Sistem Pendukung Keputusan Untuk Menentukan Penerimaan Beasiswa Bank BRI Menggunakan FMADM (Studi Kasus: Mahasiswa Fakultas Tehnologi Industry Universitas Islam Indonesia).

Hermanto, A. (2016). Implementasi Text Mining Menggunakan Naive Bayes Untuk Penentuan Kategori Tugas Akhir Mahasiswa Berdasarkan Abstraksinya. Teknik Informatika Universitas 17 Agustus Surabaya 1945.

Hidayatullah, A. F., \& Ma'arif, M. R. (2016). Penerapan Text Mining dalam Klasifikasi Judul Skripsi. Seminar Nasional Aplikasi Teknologi Informasi (SNATi).

Kurniawan, B., Effendi, S., \& Salim Sitompul, O. 2012. Klasifikasi Konten Berita Dengan Metode Text Mining.

Laengge, I., Wowor, H. F., \& Putro, M. D. 2016. Sistem Pendukung Keputusan Dalam Menentukan Dosen Pembimbing Skripsi. Jurnal Teknik Informatika Universitas Sam Ratulangi, 9(1).

Queenson, J., Klaru, S., \& Rachmansyah, R. (n.d.). Rancang Bangun Aplikasi Klasifikasi Tema Skripsi Berdasarkan Abstrak Menggunakan Knuth Morris Pratt dan Naïve Bayes Classifier. 